\title{
Anaerobic Digestion for Energy and Pollution Control
}

\author{
Philip R. Goodrich P.E. ${ }^{1}$, David Schmidt P.E. ${ }^{1}$, Dennis Haubenschild ${ }^{2}$ \\ ${ }^{1}$ Department of Biosystems and Agricultural Engineering, University of Minnesota, \\ 1390 Eckles Avenue, St. Paul, MN 55108 \\ ${ }^{2}$ Haubenschild Farms, 7201 349th Ave. NW, Princeton, MN 55371
}

\begin{abstract}
Anaerobic digestion is again being taken seriously because of increasing concerns about the environmental hazards of manure. The push to produce more renewable energy locally as a means to reduce dependence on fossil fuels has also had an effect. A well running plug-flow digester on the Haubenschild dairy in Princeton, Minnesota has provided nearly five continuous years of electrical energy production and operational data. The digester was initially installed at Haubenschild Farms to control air pollution and to produce energy by utilizing waste. The 800 cows at the farm produce enough methane to generate about $2900 \mathrm{kWh}$ per day of electricity, $1500 \mathrm{kWh}$ of which is used on the farm. The remainder is sold as "Green Energy" and marketed to consumers who wish to use electricity generated from renewable sources. The digester is producing at least 30 percent more biogas than the design estimates. The dairy also saves $\$ 400$ per month in heating costs by using waste heat from the generator. The up time on the generator has been about $95 \%$. This project has shown that a payback of 5 years or less on investment is possible.
\end{abstract}

Keywords. Anaerobic Digestion, Methane, Odor, Pollution Control, Energy, Biogas

\section{INTRODUCTION}

Anaerobic digestion for manure treatment is again being taken seriously because of increasing concerns about the environmental hazards of manure. Due to odor and nutrient concerns from neighbors, the ability of existing animal producers to expand or modernize their operations is complicated. There has also been the push to produce more renewable energy locally in order to reduce dependence on fossil fuels. These factors have led to an increased interest in anaerobic digestion for manure treatment. This article discusses a well-running plug-flow digester that has provided nearly five continuous years of electrical energy production and operational data.

Haubenschild Dairy Farm Inc. in Princeton, Minnesota is currently operating a plug flow anaerobic digester coupled with an engine generator for production of electricity with heat as a byproduct. The anaerobic digester was built in 1999 in conjunction with a dairy herd expansion from 200 cows to the current 800 cows. The cows are housed in two naturally ventilated free stall barns. The free stalls have mattresses and the cows are bedded with recycled newsprint. Manure (solids content of approximately $10 \%$ ) is scraped from the barn three times per day at milking to a $12^{\prime}$ x $12^{\prime}$ x $240^{\prime}$ cross alley collection pit. This manure then flows to a $14^{\prime} \times 14^{\prime} \mathrm{x}$ 14 ' reception pit. Approximately 11,000 gallons are pumped from the reception pit twice per day

P. Goodrich, D. Schmidt, and D. Haubenschild. "Anaerobic Digestion for Energy and Pollution Control". Agricultural Engineering International: the CIGR Ejournal. Manuscript EE 03001. Vol. VII. August, 2005. 
to the plug-flow digester. The digester is an insulated concrete tank (30' $\left.\mathrm{x} 14^{\prime} \mathrm{x} 130^{\prime}\right)$ with a high-density polyethylene (HDPE) cover. Manure from the digester flows over a weir and into a 3.2 million gallon HDPE lined manure storage pond. The manure is pumped from the storage pond throughout the year and injected into corn land or surface applied to alfalfa fields using a 7500-gallon manure tank wagon. Methane gas from the digester is used in an engine generator to produce electricity.

The driving force of this successful system is the owner, Dennis Haubenschild who has pursued a twenty-year dream of installing a digester on his farm. A champion of the system, he has spent innumerable hours encouraging local officials, friends, family and state officials to support the project. He has kept good records of costs and output from the digester.

\section{BIOGAS PRODUCTION}

Biogas production from the digester is greater than anticipated. The measured amount flowing through the engine generator (fig.1) is approximately 70,000 cubic feet of biogas per day (approximately $87 \mathrm{ft}^{3} /$ cow per day). This value is achieved after the biogas production has stabilized. This is $30 \%$ above the biogas design figures of $65 \mathrm{ft}^{3} /$ cow per day. The majority of the biogas is used to run an electric generator. Excess gas is burned in a flare that operates an estimated $60 \%$ of the time. The owner estimates that he is flaring $10-15 \mathrm{ft}^{3}$ per minute $(20-30 \%$ excess) and plans to install a meter in the future to measure the flared gas. Therefore all the figures in this paper are conservative. Biogas production throughout the five years of operation has been very stable. The biogas is approximately $60 \%$ methane and $40 \%$ carbon dioxide.

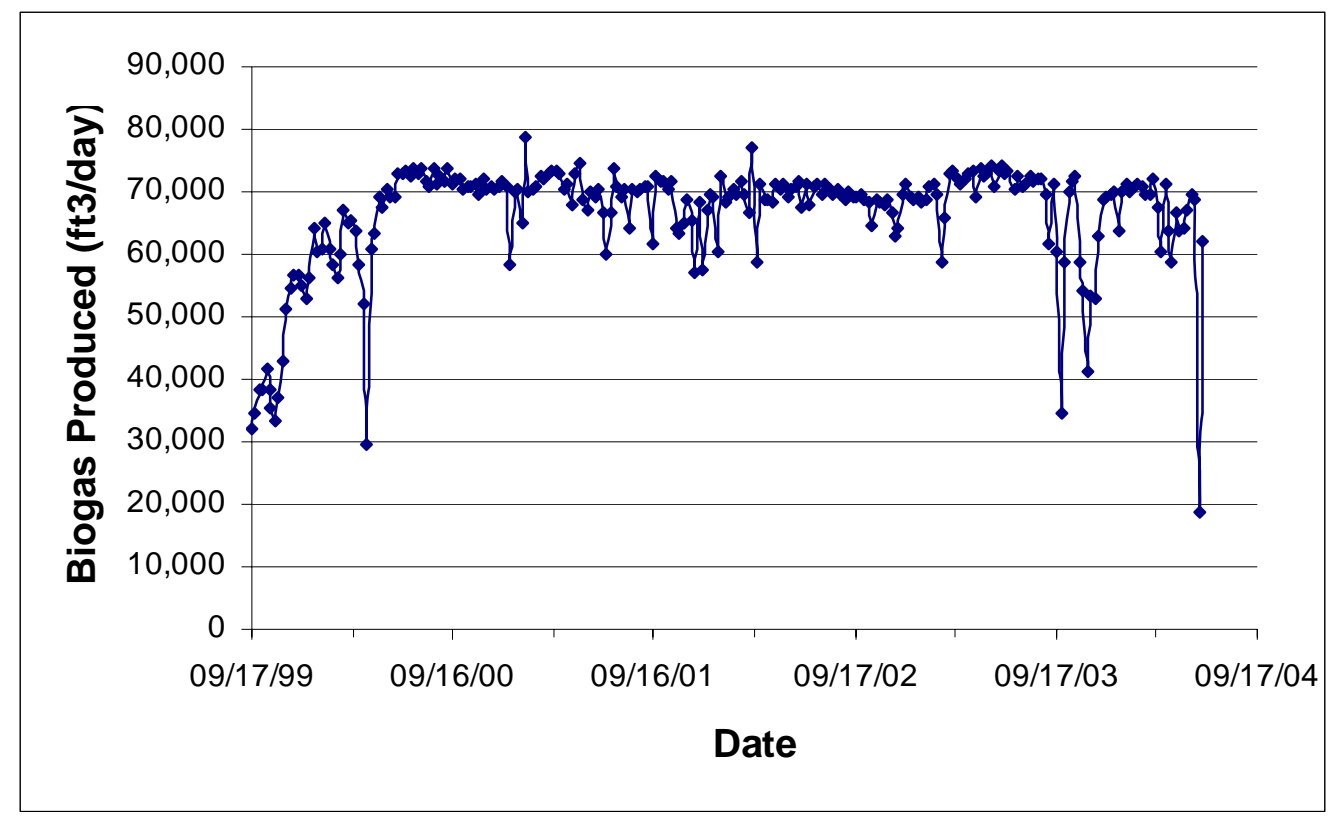

Figure 1. Daily biogas production - consumed by the engine generator (weekly average)

P. Goodrich, D. Schmidt, and D. Haubenschild. "Anaerobic Digestion for Energy and Pollution Control”. Agricultural Engineering International: the CIGR Ejournal. Manuscript EE 03001. Vol. VII. August, 2005. 


\section{ENERGY PRODUCTION}

Methane from the digester is used to power a CAT 3406 engine, which drives a $150 \mathrm{~kW}$ generator. Approximately $2900 \mathrm{kWh}$ of energy is generated each day while the dairy operation uses approximately $1500 \mathrm{kWh}$ per day. The excess electrical energy is sold back to the local energy cooperative at 7.25 cents per $\mathrm{kWh}$. Figure 2 shows the weekly electrical generation and consumption since operation began. Recovered thermal energy from the engine is used to heat the anaerobic digester (maintained at 100 degrees $\mathrm{F}$ throughout the year), the floors of the free stall barn, and the milking parlor.

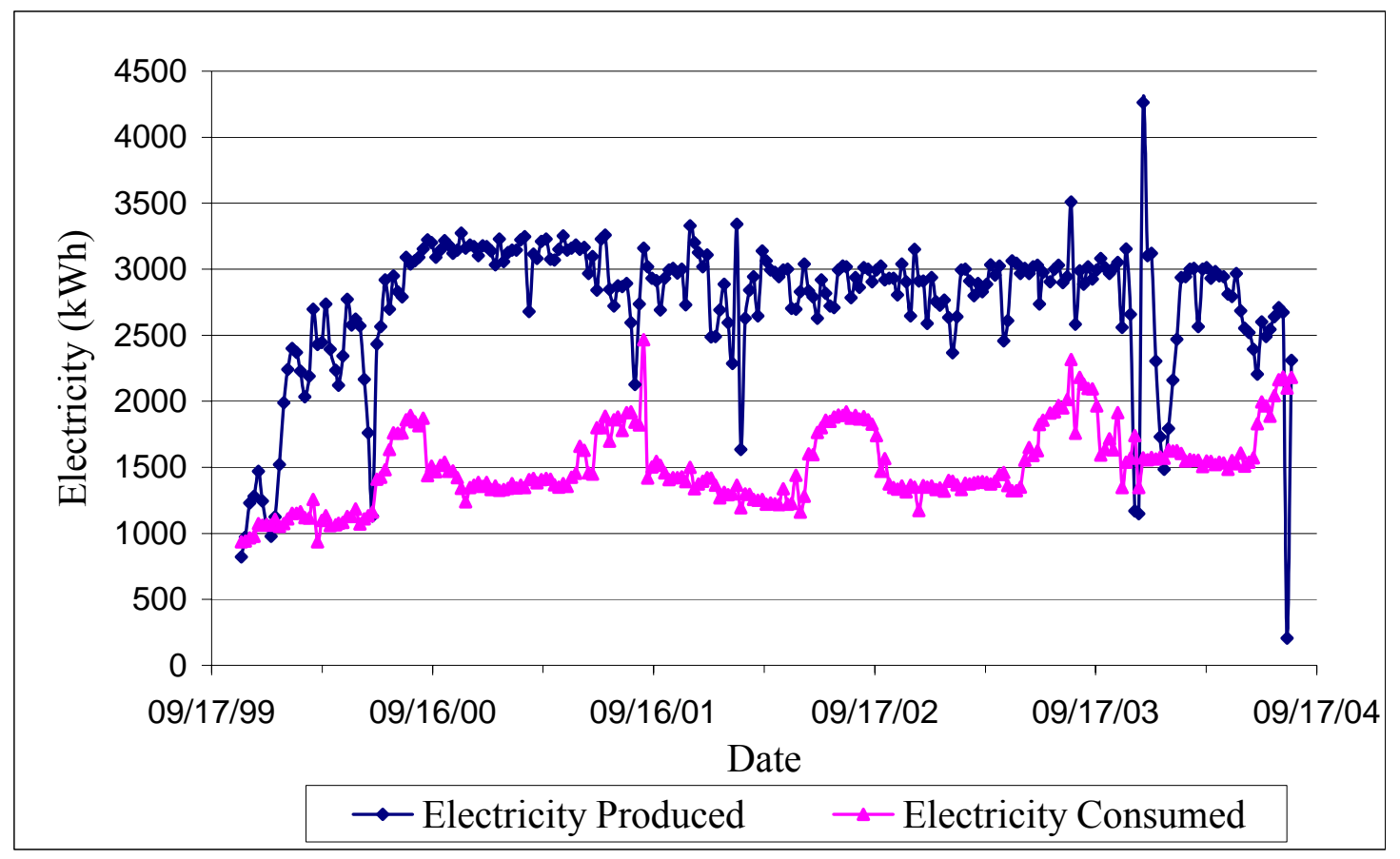

Figure 2. Daily consumption and generation of electricity (weekly average)

\section{ECONOMIC ANALYSIS}

Initial investment in the anaerobic digester system was $\$ 355,000$. Payback on the system at $10 \%$ interest and the current energy production/utilization is estimated at 5-7 years. This payback does not include heat energy used in the free stall barn and parlor or the other benefits of odor reduction, weed seed and pathogen reduction, and possible crop response benefits. The University of Minnesota is currently researching all of these "other" benefits through a National Resource Conservation Service (NRCS) funded research project.

For comparison, using the $\$ 355,000$ cost of the system as a 10 -year mortgage, the monthly payment on interest and principal would be $\$ 4691$ at a $10 \%$ interest rate and $\$ 4307$ at $8 \%$ interest. Selling the electricity back to the energy co-op yields approximately $\$ 3390$. The

P. Goodrich, D. Schmidt, and D. Haubenschild. "Anaerobic Digestion for Energy and Pollution Control”. Agricultural Engineering International: the CIGR Ejournal. Manuscript EE 03001. Vol. VII. August, 2005. 
electricity generated for use on the farm which offsets purchased electricity plus sold electricity easily meets the costs of the system.

\section{SAFETY EMPHASIS}

The digester has been designed to meet safety considerations for manure pollution control. The concrete structures exceed the Natural Resources Conservation Service and Minnesota Pollution Control Agency standards. The storage pond is lined with polyvinyl chloride and is fenced to keep animals away. Safety devices are in place to limit the pressure on the digester cover. Placards warn of dangers throughout the electrical system and guards are placed to keep people and animals out of dangerous locations.

\section{FEASIBILITY OF ANAEROBIC DIGESTERS ON MINNESOTA FARMS}

The system in place at Haubenschild Farms is one success story, but the feasibility of anaerobic digestion is, in general, very site specific. Following, is a discussion of some of the factors to consider in determining the suitability of anaerobic digestion for a given site.

First of all, often by looking solely at the economic return from electrical production and sale, the economic evaluation is unfavorable for many types and sizes of operation. However, in these evaluations, the secondary benefits, such as odor control, pathogen reduction measures and weed seed reduction, are often neglected; but they have the potential to be highly beneficial to the system's economic return. Unfortunately, it is difficult to assess specifically the economics of these secondary benefits.

The first factor to consider when evaluating the feasibility of an anaerobic digester is the primary goal of the digestion system. If the primary goal is economical odor control, then the cost and performance of the digester should be compared to the cost and performance of other technologies in achieving the same level of odor control. For instance, anaerobic digestion is estimated to reduce odor from manure storage and land application by $60-90 \%$. However, anaerobic digestion will not reduce odors coming from the barns or other manure sources. In contrast, a biofilter will remove odors from the barns but not from the manure storage. Therefore, a feasibility study of anaerobic digestion must begin with an assessment of the odor sources on the farm, the priorities of odor reduction, and the variety of options available.

The second factor in evaluating the economics of anaerobic digestion is the level of complexity of the system. There are a number of permutations for the systems ranging from a simple, covered storage basin with methane flare, to a completely mixed flow reactor with engine and generator. Several system options must be considered in determining the feasibility.

The most basic anaerobic digestion system is a covered manure storage and methane flare. This system is the most economical because the only cost involved is the cover and flare. However, with this system there are no cash economic returns. To achieve some return on this investment, some farms have chosen to add a heat recovery system. The benefits of odor control are often the reason for this low cost system.

P. Goodrich, D. Schmidt, and D. Haubenschild. "Anaerobic Digestion for Energy and Pollution Control”. Agricultural Engineering International: the CIGR Ejournal. Manuscript EE 03001. Vol. VII. August, 2005. 
Instead of flaring the methane captured by the cover, the methane is burned in a boiler and the hot water is used for heating buildings. This is a relatively inexpensive option that provides some economic return.

The next level of investment with potential return is to install a completely mixed or plug-flow digester. This digester increases the amount of methane produced that can be used in the boiler system. Considerations for this option must include the heat use on the farm. Many facilities (dairy and swine finishing operations) have limited need for additional heat on the farm so the additional benefit of this upgrade must be carefully considered.

The next upgrade in an anaerobic digestion system is to include an engine/generator set to produce electricity. This is a significant investment but also has the potential to generate some economic return from the sale of excess electricity or by offsetting current electrical charges. High-energy use (electrical) facilities such as dairies or nursery barns will benefit the most from an upgrade to electricity production.

All of these anaerobic digestion systems result in manure with reduced odor, but only those with heated digesters will benefit from the reduced viable weed seed count and reduced pathogens. If these are critical issues, there may be some additional benefit to constructing a digester besides increased methane production and increased heat or electrical output. Current research at the University of Minnesota is assessing these other benefits.

There are many factors involved in assessing an anaerobic digestion system. These factors include the potential for energy production and sale, economic factors such as interest rates and available financial assistance, and finally the value of the system's secondary benefits. With all the variables to consider when assessing the feasibility of an anaerobic digester, it is safest to ask for assistance from someone with experience in the design and construction of these systems. A self-assessment checklist to determine the feasibility of an anaerobic digester developed for the Minnesota Agricultural Utilization Research Institute can be found at http://www.auri.org/research/digester/diglead.htm.

Other information on anaerobic digestion can be found under the topic heading "Treatment" on the University of Minnesota Manure web page at: www.bae.umn.edu/extens/manure

The USEPA AgSTAR program (http://www.epa.gov/agstar/) (US EPA 1997) developed software (FarmWare 2.0) to assess the feasibility of anaerobic digesters. Two studies (Garrison and Richard 2001, and Hind 2002) have used this software to estimate economic feasibility of anaerobic digestion on several types and sizes of farms. Results from Garrison and Richard (2001) are found in Table 1. These results suggest that the breakeven costs for anaerobic digesters require fairly large animal number (large volumes of manure). However, this analysis did not include the other economic benefits of those items discussed earlier (e.g. odor and pathogen reduction).

P. Goodrich, D. Schmidt, and D. Haubenschild. "Anaerobic Digestion for Energy and Pollution Control”. Agricultural Engineering International: the CIGR Ejournal. Manuscript EE 03001. Vol. VII. August, 2005. 
Table 1. Economic breakeven* points for anaerobic digestion systems using Farmware

\begin{tabular}{|c|c|c|c|c|c|c|}
\hline \multirow[t]{2}{*}{ Facility } & \multicolumn{6}{|c|}{ Head Size Breakeven Point for Scenarios (see table 2) } \\
\hline & $\# 1$ & $\# 2$ & \#3 & $\# 4$ & $\# 5$ & \#6 \\
\hline Swine Farrow to finish & $>20,000$ & $>20,000$ & $>20,000$ & $>20,000$ & $>20,000$ & $>20,000$ \\
\hline Swine Finish & $>20,000$ & $>20,000$ & 4792 & 13949 & $>20,000$ & 1856 \\
\hline Dairy Tie-Stall $\mathrm{PF}^{+}$ & $>5000$ & $>5000$ & 222 & $>5000$ & $>5000$ & 1090 \\
\hline Dairy Tie-Stall $\mathrm{CM}^{\ddagger}$ & $>5000$ & $>5000$ & 148 & $>5000$ & $>5000$ & 314 \\
\hline Dairy Free-Stall, PF & $>5000$ & $>5000$ & 234 & $>5000$ & $>5000$ & 1230 \\
\hline Dairy Free-Stall CM & $>5000$ & $>5000$ & 148 & $>5000$ & $>5000$ & 330 \\
\hline
\end{tabular}

*Breakeven is defined as having a Net Present Value of 0.

${ }^{\mathrm{PF}}=$ Plug Flow $\quad{ }_{\mathrm{f}} \mathrm{CM}=$ Complete Mix

(Garrison and Richard, 2001)

A study by Hinds (2002) also reviewed the economic feasibility of anaerobic digestion systems using FarmWare (Table 2). The results of this analysis are somewhat more favorable. Here, breakeven costs occurred in dairy facilities with as few as 400 cows. The differences between these two studies (Garrison and Richard, 2001 and Hind, 2002) are unclear however the likely differences are minor.

Another noteworthy comparison between the modeling software, FarmWare, and the actual case at Haubenschild Dairy Inc., are their differing economic results (Table 3). FarmWare under predicted both the capital cost and the methane production for the system. However, its prediction of a payback time on the investment of six years was fairly close to the actual value. Unfortunately, this scenario is not likely for most producers because the rate for excess electricity sold back by Haubenschild Dairy was unusually high (7.25 cents per kWh). Current rates for electrical buyback in Minnesota are estimated to be 3.4 cents per $\mathrm{kWh}$ plus an additional 1.5 cents incentive payment from the state. Using this rate of return on the sale of electricity ( 5.7 cents per $\mathrm{kWh}$ ) the loan payback on the Haubenschild system would be 7.5 years instead of the 5.5 years (using 20\% down payment on investment and $10 \%$ annual rate of interest on the loan). Estimates from FarmWare with 7.25 cents per $\mathrm{kWh}$ payment for electricity result in an estimated payback period of 6.5 years.

Table 2. Assumptions for scenarios in Table 1

\begin{tabular}{ccccc}
\hline Scenario \# & $\begin{array}{c}\text { Electrical } \\
\text { Rate }\end{array}$ & $\begin{array}{c}\text { Propane heat } \\
\text { \% heat supplied } \\
(\$ / \text { gal })\end{array}$ & $\begin{array}{c}\text { Loan Rate } \\
(\%)\end{array}$ & $\begin{array}{c}\text { Producer Down } \\
\text { payment } \\
(\%)\end{array}$ \\
\hline 1 & 0.06 & 0 & 10 & 20 \\
2 & 0.08 & 0 & 10 & 20 \\
3 & 0.12 & 0 & 10 & 20 \\
4 & 0.06 & $90(1.00)$ & 10 & 20 \\
5 & 0.06 & 0 & 0 & 5 \\
6 & 0.06 & $90(1.00)$ & 0 & 5 \\
\hline
\end{tabular}

P. Goodrich, D. Schmidt, and D. Haubenschild. "Anaerobic Digestion for Energy and Pollution Control". Agricultural Engineering International: the CIGR Ejournal. Manuscript EE 03001. Vol. VII. August, 2005. 
Table 3. ${ }^{*}$ Comparison of predicted and actual economics of Haubenschild anaerobic digester.

\begin{tabular}{|c|c|c|c|}
\hline$\underline{\text { Plug Flow Digester }}$ & FarmWare & Actual & $\begin{array}{c}\text { Actual with } \\
3.4 \text { cents } / \mathrm{kWh}\end{array}$ \\
\hline Total cost: & $\$ 289,116$ & $\$ 355,000$ & $\$ 355,000$ \\
\hline - Mix tank: & $\$ 21,515$ & $\$ 32,400$ & $\$ 32,400$ \\
\hline - Digester: & $\$ 110,132$ & $\$ 125,100$ & $\$ 125,100$ \\
\hline - Engineering: & $\$ 25,000$ & $\$ 40,000$ & $\$ 40,000$ \\
\hline - Generator: & $\$ 132,469$ & $\$ 157,500$ & $\$ 157,500$ \\
\hline Annual O\&M (\$/yr.): & $\$ 13,230$ & $\begin{array}{r}\$ 17167 \\
\text { (est) }\end{array}$ & $\$ 17167$ (est) \\
\hline Annual Benefits (\$/yr.): & $\$ 63,947$ & $\$ 86,973$ & $\$ 72,099$ \\
\hline - Electricity $(\$ 0.0725 / \mathrm{kWh})$ : & $\$ 63,947$ & $\$ 82,973$ & $\$ 58,605$ \\
\hline - Propane: & - & $\$ 4,000$ & $\$ 4,000$ \\
\hline - State Incentive ( $\$ 0.015 / \mathrm{kWh})$ & & & $\$ 9,494$ \\
\hline \multicolumn{4}{|l|}{ Energy Produced: } \\
\hline Electricity $(\mathrm{kWh} / \mathrm{yr}$.$) :$ & 882,022 & $1,144,450$ & $1,144,450$ \\
\hline \multicolumn{4}{|l|}{ Installation information: } \\
\hline Number of Cows & 1000 & 800 & 800 \\
\hline Generator $(\mathrm{kW})$ : & 112 & 150 & 150 \\
\hline Biogas ( $\mathrm{ft} 3 /$ day): & 65,000 & 71,000 & 71000 \\
\hline Manure (gal/day): & 18000 & 22000 & 22000 \\
\hline \multicolumn{4}{|l|}{ Assumptions: } \\
\hline Total cost $(\$ /$ cow $)$ & $\$ 289$ & $\$ 444$ & $\$ 444$ \\
\hline Generator cost $(\$ / \mathrm{kW})$ & $\$ 1,183$ & $\$ 1,050$ & $\$ 1,050$ \\
\hline Electricity (kWh/cow/yr.) & 882 & 1431 & 1431 \\
\hline Electricity (kWh/cow/day) & 2 & 4 & 4 \\
\hline Generator size ( $\mathrm{kW} / \mathrm{cow})$ & 0.11 & 0.35 & 0.35 \\
\hline Biogas (ft3/cow/day) & 65 & 89 & 89 \\
\hline Manure (gal/cow/day) & 18 & 27 & 27 \\
\hline
\end{tabular}

*(Nelson and Lamb 2000)

\section{IMPACT ON GREENHOUSE GAS}

The digester reduces emissions of methane, carbon dioxide and ammonia from manure while in the enclosed vessel. Combustion of the biogas releases some carbon dioxide and sulfur compounds back into the atmosphere. However this combustion process releases carbon dioxide, which was captured by plants in the last year by the crop fed to the animals in contrast to fossil fuels, which are releasing carbon from ancient biomass.

P. Goodrich, D. Schmidt, and D. Haubenschild. "Anaerobic Digestion for Energy and Pollution Control". Agricultural Engineering International: the CIGR Ejournal. Manuscript EE 03001. Vol. VII. August, 2005. 


\section{CONCLUSION}

The strong support of a champion is beneficial to a project having the magnitude of the Haubenschild Digester. Garnering additional support and seeing the project through takes time and concerted effort. The economic reality of being paid retail rates for the excess energy as well as avoiding the cost of buying energy for the dairy operation is enormous. The excellent management of the dairy barn with biodegradable bedding is an added plus. A sand bedded operation would create some very difficult problems for a digester. The high percentage of operation time has also been very beneficial to the operation. Others contemplating anaerobic digestion as a manure management system will need attention to detail and persistence in getting the job done right so the project will succeed.

\section{ACKNOWLEDGEMENTS}

The authors acknowledge the great assistance of Dennis Haubenschild who has been the champion behind this digestion system. The Minnesota Project gathered support and organized the many persons who served on advisory committees, which met often to help in the project. The State of Minnesota provided funds through several organizations including Minnesota Extension, Minnesota Department of Commerce, Minnesota Pollution Control Agency, and Agricultural Utilization Research Institute. The United States Government assisted through the USDA Natural Resources Conservation Service. The Great River Energy Cooperative assisted in facilitating the energy agreements.

\section{REFERENCES}

Garrison, M. V., and T. L. Richard. 2001. Final Report for the Iowa Livestock Industry Waste: Characterization and Methane Recovery Information Dissemination Project, Iowa Department of Natural Resources, Energy \& Geological Resources Division, Des Moines, IA 50319-0034

Hinds, Paul, 2002. Personal communication. Minnesota's Potential for Electricity Production Using Biogas Resources

Nelson, Carl and John Lamb. 2000 Haubenschild Farms Anaerobic Digester, Final Report. The Minnesota Project.1885 University Avenue, Suite 315, St. Paul, MN 55104. 35 pp.

U. S. EPA. 1997. AgSTAR Handbook A Manual For Developing Biogas Systems at Commercial Farms in the United States. Edited by K. F. Roos and M. A. Moser. EPA 430-B97-015. Washington, D.C.

P. Goodrich, D. Schmidt, and D. Haubenschild. "Anaerobic Digestion for Energy and Pollution Control”. Agricultural Engineering International: the CIGR Ejournal. Manuscript EE 03001. Vol. VII. August, 2005. 